\title{
Remembering the Future: what do children think?
}

\author{
DAVID HICKS Bath Spa University
}

CATHIE HOLDEN University of Exeter

SUMMARY This paper looks at the growing interest in exploring alternative futures and in particular at the need for a futures perspective in education. It looks at the ways in which educators are responding to this and at the concerns expressed by young people themselves about the future. The value of a futures perspective in work exploring issues of environment and sustainability, whether in local or global contexts, is stressed.

\section{Exploring futures}

Whilst the future is present in all human actions and interactions it is seldom, at least in popular terms, something made explicit or examined in detail. This may be because, as Wagar argues, 'the future is a very murky place. There are no eye-witness accounts, no first-hand evidence' (1992:34). Since the future does not exist it clearly cannot be studied and is thus seldom thought of as an appropriate academic concern. And yet the international field of futures studies, which has been in existence for nearly half a century, offers a wealth of expertise and insight for those who wish to think more critically and creatively about the future (Bell, 1997; Sardar, 1999; Slaughter, 2005).

Inayatullah (1993: 236) succinctly describes the field when he writes ' ...futures studies largely straddles two dominant modes of knowledge - the technical concerned with predicting the future and the humanist concerned with developing a good society.' Bell, Emeritus Professor of Sociology at Yale, argues that the purposes of futures studies 'are to discover or invent, examine and evaluate, and propose possible, probable and preferable futures. Futurists seek to know: what can or could be (the possible), what is likely to be (the probable), and what ought to be (the preferable)' (1997: 73).

Dator elaborates further when he writes:

'The future' cannot be 'studied' because 'the future' does not exist. Futures studies...studies ideas about the future (what I usually call 'images of the future') which each individual and group has... These images often serve as the basis of actions in the present... They often change over one's lifetime. Different groups often have very different images of the future. Men's images may differ from women's. Western images may differ from non-Western images, and so on.

The future cannot be 'predicted', but 'alternative futures' can, and should be 'forecast'. Thus, one of the main tasks of futures studies is to identify and examine the major alternative futures which exist at any given time and place (Dator, 2005).

Because practitioners come from many fields they do not necessarily use the term 'futures studies' but the principles by which they work closely relate to the principles set out by Bell 
and Dator above. Meadows et al. (2005), for example, have long used futures scenario modelling in their work on global 'limits to growth'. The Worldwatch Institute (2005) publishes its annual report Vital Signs, which reports on the social and environmental trends that are shaping the future. Jude et al. (2003) at the Tyndall Centre use future scenarios in their work with local communities that are in danger of coastal flooding. Barbara Adams at Cardiff University is responsible for an ESRC funded social science project entitled 'In Pursuit of the Future' (www.cardiff.ac.uk/sosi/futures/index.html). Climate scientists in particular are concerned about possible, probable and preferable futures in relation to what seems like accelerating climate change (www.ukcip.org.uk/scenarios).

\section{Futures in education}

Whilst earlier work (Hicks and Holden, 1995a) argued that the future was a missing dimension in environmental education Rickinson (2001) later highlighted the importance of young people's views of the future in identifying evidence of environmental concerns. Given that environmental education and education for sustainability both have a concern for a) the current state of the planet and b) human responsibility for the environment, then these fields are implicitly involved with probable and preferable futures. To embrace what one might call a 'futures perspective' more explicitly requires deeper engagement with the insights of futures studies.

The nature of futures studies in higher education has been well mapped out by Dator (2002) who brings together contributions from major futurists working in the field. Taken together these embrace overviews and histories of futures studies, explorations of futures practice and methodologies, and examples of teaching and research from a number of different countries. Comparative international research on 'youth futures' has been brought together by Gidley and Inayatullah who note that 'The youth who speak through these pages have a destiny that comes with being born into these crucial times. Many of them, angry about the damage to the earth they have inherited from previous generations, are strongly committed to trying to change things for the better' (2002: 242). Interesting work in Australian schools has been chronicled by Gidley, Bateman and Smith (2004) with environment always one of the concerns uppermost in young people's lives.

Tasmania's Department of Education (2002) has identified a number of essential learnings which need to run through the school curriculum. These include:

- Personal futures - Learners will be self-directed and ethical people having a positive vision for themselves and the future, acting with moral autonomy and contributing to constructive futures for themselves and others. Ethical dilemmas abound in the modern world and learners increasingly need to examine value positions implicit in issues, to think critically about all perspectives to determine their own position and contribute to preferred futures for themselves and their community.

- World futures - learners will be world contributors willing to consider the consequences of scientific and technological innovations, make thoughtful decisions about their application, and to maintain, protect and enhance local and global environments.

Including personal and world futures in this way as key elements in over-arching learning goals helps legitimate the exploration of alternative futures in the classroom. The need for futures to be explored in school, however, is still not widely recognised and, with the 
exception of sources cited later in this article, there is still a lack of innovative teaching materials that draw on crucial insights from futures studies. Hutchinson notes that school books generally have little to say about alternative futures arguing that:

Whether in relation to our schools, our societies or our species, when taken-forgranted ways of thinking about the future are left unexamined, a closure of horizons occurs - futures are foreclosed and 'inevitabilities' are confirmed as 'realism' (Hutchinson 1996: 48).

What children and young people need is guidance on how to think more, rather than less, critically and creatively about the future, whether personal, local or global. The ability to thus interrogate different possible futures is what Slaughter (2004) calls 'futures in education.'

\section{Young people's concerns}

There is now a growing literature (see below) which explores children's concerns for the future. This makes it possible to identify the nature and range of those concerns from early years, through primary to secondary and beyond. Environment is a consistent theme.

\section{Early years}

Page investigated the hopes and fears of four and five year olds in Australia and found that they 'were clearly engaged by current issues of pollution, the environment, contemporary music and warfare' (2000: 31 ). When talking about the environment, the children illustrated an emerging awareness of the negative effects of deforestation, global warming and rubbish/litter. Whilst these children had difficulty defining the future from an adult perspective, they were nonetheless able to envisage the world they would like when they grew up. Their futures were a combination of different scenarios: some fantastic, some based on stories and some based on the adult world they knew. Page notes the creativity and hope in young children's images in contrast to the views of older children which are 'frequently locked within a received framework of conventional, dystopian science fiction imagery' (2000: 27). Elm (2006) researching the views of four to six year olds in Sweden found that whilst they had problems thinking globally, they were well able to talk about their personal futures and that of their local community, where they were keen that things should 'stay the same', but with less litter and 'more animals, trees and flowers'. Page (2000) and Masini (1986) both argue the need for a clear futures perspective in the early years curriculum as young children are already developing futures awareness at this stage

\section{Primary}

Research in the mid-90s (Hicks and Holden, 1995b) was the first to explore hopes and fears for the future of UK pupils, making it possible to trace the development of children's thinking about the future. In this study the primary children aged 7 and 11 showed a growing awareness of social and environmental issues and were concerned that their local communities would be affected adversely by increasing violence, unemployment and racism and a lack of facilities for young people. Similar concerns were expressed at a global level, with many children being worried about the possibility of an increasing number of wars. Ten years later this study has been repeated and it is this research that is reported on here. 
The study involved 525 nine, eleven and fourteen year olds from twelve primary schools and four secondary schools in the south of England. Schools were selected from a cross section of urban and rural environments and a variety of socio-economic backgrounds. Four of the twelve primary schools were those used in the original 1994 survey. In each case all pupils in the class were involved.

The questionnaire incorporated elements from the 1994 study so that comparisons could be made. As with the earlier study the focus was on children's views of the future at personal, local and global levels. Firstly, children were asked to write about their hopes and fears for their personal future, the future of their local area and the future of the world. The open ended nature of the questions allowed for a variety of responses. Secondly, there were closed questions which focused on particular issues, such as violence, prejudice, environment, poverty. In each case children were asked if they thought the issue would be more or less important in the future or would stay the same. Finally, children were asked whether they were involved in any organization that was working for change and also whether they had learnt about such issues at school. A small group of children from each class was then invited to say more about the thinking behind their responses to specific questions. We were also mindful of ethical considerations and felt that group interviews were less stressful for the children (Lindsay 2000).

Responses to the closed questions yielded descriptive statistics showing the percentage of responses to predetermined answers on a three or five point scale. Open questions were coded for emerging themes and then represented statistically in terms of the percentage of children voicing particular perceptions. The findings from the eleven year olds are discussed here as they can be directly compared to the same age group surveyed in 1994. The findings from the fourteen year olds are discussed in the secondary section, below.

Responses to the open ended questions indicate that eleven year old children today have a clear desire for a better quality of life in their local community. They want more amenities, affordable housing, better relationships between people, less crime and violence and an end to racism. There is an overwhelming desire for peace, less violence and poverty and a solution to environmental problems in the wider world. Most children thought levels of conflict, racism and violence would stay the same in their local area, although a third were optimistic that poverty and racism would become less important. The exception is in relation to environmental matters, where over two thirds thought there would be more problems in the future. When asked about global problems the children were generally more negative, and again the environment stands out as a key concern for the future.

TABLE 1. Perceived importance of local issues in the future

\begin{tabular}{|l|l|l|l|l|}
\hline $\begin{array}{l}\text { Local } \\
\text { issues }\end{array}$ & Poverty & Prejudice & Violence & Environment \\
\hline More & 19 & 27 & 32 & 68 \\
\hline $\begin{array}{l}\text { The } \\
\text { same }\end{array}$ & 50 & 47 & 53 & 23 \\
\hline Less & 30 & 26 & 15 & 8 \\
\hline
\end{tabular}

11 year olds (as \%) $(\mathrm{N}=217)$ 
TABLE 2. Perceived importance of global issues in the future

\begin{tabular}{|l|l|l|l|l|}
\hline $\begin{array}{l}\text { Global } \\
\text { issues }\end{array}$ & Poverty & Prejudice & Violence & Environment \\
\hline More & 35 & 38 & 61 & 68 \\
\hline $\begin{array}{l}\text { The } \\
\text { same }\end{array}$ & 35 & 33 & 25 & 19 \\
\hline Less & 30 & 26 & 13 & 12 \\
\hline
\end{tabular}

11 year olds (as \%) $(\mathrm{n}=217)$

Responses from both open ended questions and interviews showed that their hopes and fears related to both the built and natural environment. They were concerned about loss of parks and places to play, about increased pollution, trees being cut down, litter, loss of wildlife and 'more factories'. Traffic was a particular concern: they wanted less traffic, better roads, safer drivers, more cycling and more pedestrian crossings. Their visions of an environmentally friendly local community reflected their current situation as users of bikes and local spaces but also indicated an awareness of the dangers of increasing urbanization and loss of natural resources. Concerns about global environmental issues related to 'less pollution', more recycling and an end to global warming. There were also fears about the destruction of trees, the extinction of animals and the disappearance of the countryside. It was the environment which frequently sparked off discussion in interviews.

I think [there will be] more problems because of global warming. Like Bush is associated to Esso and Esso are saying that they take up the world's toughest challenges and they don't really. They just take petrol from Iraq and just use it and they say 'we're taking a million cars off the road each year' and I think they're lying. I just think global warming should be stopped and the war on terror. (Boy: 11)

I think more problems because like people want all these fancy things to be built so they're going to be cutting down more and more trees. Like in Bideford when they were building on the quay they only needed to cut down a couple of trees to get the machinery in but they cut down all of them.

(Girl: 10)

Whilst many children cited environmental issues that they may have heard about on the news or witnessed in their community, some also showed a lack of understanding of such issues. However, discussions in interview revealed both a genuine concern about environmental issues and also a desire to be better informed and to know what they could do. Regardless of their level of understanding the majority of children thought they could do something to bring about change. When asked what they did to make their local community or the world 'a better place', their responses fell into three broad categories: i) environment; ii) action and campaigns; iii) relationships.

The environment was most frequently mentioned with children saying they did not drop litter, they recycled, saved energy or walked to school. They cited 'sharing lifts to school' and 
'buying stuff with less packaging' as examples. One in three mentioned their involvement in campaigns or fundraising, usually linked to work at school. They talked about Oxfam, Christian Aid, Comic Relief, Blue Peter, Children in Need and cancer charities.

It is interesting to note that these primary children were more likely to see the environment as an area of concern than their counterparts a decade earlier. Half of the 1994 sample thought environmental problems would increase, compared to three quarters in 2004. Children in 1994 mainly focused on pollution from factory emissions and car exhausts alongside the need for clean air and 'no litter'. On a global scale there was mention of climate change or the need for alternative fuels. Ten years on there was less talk of pollution and much more discussion about climate change and problems caused by increasing development and numbers of cars.

\section{Secondary}

Research into secondary pupils' concerns shows they have similar concerns to primary children but become increasingly pessimistic about both local and global futures as they grow older. Research from Finland shows young people optimistic about their own future but less optimistic about the future for their country. They fear that it will descend into 'a society of corruption, unemployment, growing environmental problems, drugs and dirty urban centres full of poor people struggling for their livelihood' (Rubin, 2002: 103). Their concerns for the global community centre on poverty and hunger, wars, overpopulation and environmental pollution. Similar findings are reported by Oscarsson, whose Swedish students hold positive views about their own future but are less optimistic about the future for Sweden, where economic conditions are seen as uncertain and they are less optimistic still about the global future. Like their Finnish counterparts their fears are around environmental issues and global conflict (Oscarsson, 1996).

Our earlier research (Hicks and Holden, 1995b) resonates with the above. We found that secondary school students (aged 14 and 18) in the UK were fairly optimistic about their personal future, but less so about the quality of life for people in their community or around the world. They were concerned that poverty, unemployment and environmental problems would increase but had little idea of what role they could play as active citizens. British fourteen year olds surveyed in this decade (Holden, 2007) had similar concerns, with violence and crime being a particular fear. When asked to consider the future of the world, they worried about world poverty, global conflict and continuing environmental problems. Like their primary counterparts, today's teenagers were less optimistic that solutions to environmental problems would be found than they were about any other key global issue. A key difference, however, between the primary and secondary young people was their involvement in action for change. Whereas many primary children considered themselves to be making a difference (citing environmental action, fundraising or campaigns) the vast majority of these teenagers claimed not to be involved in any action for change.

Eckersley (1999: 89) succinctly sums up much of the research into young people's views of the future when he writes about 15-24 year-olds in Australia;

It might be argued that people have always had visions of an ideal world and these have always been beyond the reach of reality. What is important, however, is whether the gap between the ideal and the real is perceived to be widening or narrowing. A belief in progress demands that the gap should be closing; the findings of this and 
other studies indicate that the dominant perception among young...people is that the gap is getting wider.

\section{A sense of agency}

To understand how young people conceptualise the future, whether personal, local or global, is of little value in itself. At one level it merely tells us that they are concerned about some of the things that they see happening around them and that they hope these will change in the future. Roger's (1996) research and subsequently that of Hicks (2006) noted a vital affective dimension to learning about global futures. Rogers identified five dimensions or stages of learning when she monitored what happened to students exploring futures issues. These were:

1. Cognitive dimension - learning new facts and information about the current global situation, traditionally considered to be the core of teaching about global issues. Some students felt cognitively overwhelmed by what they learnt about environmental and other issues.

2. Affective dimension - Some students experienced a wave of conflicting emotions when considering the impact of global issues on the future. These emotions ranged from excitement and hopefulness to depression and despair.

3. Existential dimension - For some being confronted with issues of sustainability or climate change can lead to deep soul searching about their values, life-purpose and ways of living.

4. Empowerment dimension - If students can work through these previous stages they begin to feel a sense of agency and empowerment arising from a clearer sense of personal and (with older groups) professional direction. In particular this arises through envisioning positive scenarios for particular futures and the steps needed for their realisation.

5. Action dimension - If the questions raised by the first four stages of learning can be satisfactorily resolved then informed personal, social and political choices and action are much more likely to follow.

Both Rogers (1996) and Hicks (2006) found that collaborative learning and sharing of concerns were vital in helping students to process their concerns and move beyond their initial disinterest, pessimism or despair.

Other case studies highlight the importance of a supportive learning environment in helping young people feel positive about their future. For example, Gidley (1998) investigated the views and visions of the future held by secondary students at a Steiner school. She found that they 'demonstrated a strong sense of activism and self-confidence and felt empowered to create their own preferred futures' (1998:395). Gidley speculates that this sense of agency arises from the philosophy and methods of Steiner education which emphasise artistic, imaginative, values-based and holistic educational experiences. Similarly, Devine-Wright et al. (2004) explored levels of self-efficacy felt by children and adults who were members of the Woodcraft Folk educational organisation. When compared with non-members they found Woodcraft Folk children to have 'higher levels of personal awareness and perceived selfefficacy in relation to global warming' (2006: 493). Again, exposure to cooperative learning environments with those sharing similar values appears to have had a significant impact on young people's sense of agency, in this case related to global warming. 


\section{Remembering the future}

\section{Children's concerns}

What the research on children's views of the future shows is that they are aware of a wide range of local and global issues and that environmental matters are a key concern for them. Whilst that anxiety has remained constant the specific focus of their environmental concern shifts somewhat in relation to contemporary events. What may have changed, as observed by Holden (2007), is an increased pessimism about environmental futures. Awareness that the future can hold both threat and promise begins in the early years and continues into adulthood. Further research, however, is needed into the possible links between hope/fears and personal and social action/inaction.

\section{Sense of agency}

The work by Rogers (1996), Gidley (1998) and Devine-Wright et al. (2004) highlights the vital importance of both educational context and empowering pedagogy in beginning to bridge the gap that is often observed between knowledge and action. This is, of course, a major concern for environmental educators as reviewed in Rickinson (2001). Those working primarily in the futures field could profitably learn from the environmental literature on this issue since one of the prime purposes of exploring possible, probable and preferable futures is to promote informed action for change.

\section{A futures perspective}

Whilst the need for a clear global dimension in the curriculum has been officially recognised (DfES, 2005; Hicks and Holden, 2007), the need for children to think more critically and creatively about the future is both under-theorised and as yet underdeveloped. Official sources in the UK tend to spend more time focusing on the future of education rather than the exploration of alternative futures within education. Two examples of this are the regional seminars held by the Training and Development Agency for Schools (Newby 2006) and the Futures Programme of the Qualifications and Curriculum Authority (2006). Both tend to deal with what Gough (1990) calls 'token' and 'taken-for-granted' futures.

\section{Classroom practice}

The value of key concepts from futures studies, such as probable and preferable futures, scenarios, envisioning, can fruitfully be employed in the classroom to help students develop a futures perspective. This involves the practice of foresight, consideration of more sustainable and ethical futures, whether personal or global, and development of a sense of present and future agency (Slaughter, 2006). Geographers have begun to take this to heart at both primary and secondary level (Roberts, 2003; Morgan, 2006) as have some citizenship educators (Wales and Clarke, 2005). A clearer notion of futures efficacy is also beginning to emerge in consultative documents on the need for more sustainable schools (DfES, 2006).

\section{Research needed}

The field of futures education is, as yet, under-researched and there are a number of questions that require investigation. These include: i) how do young people's views of the future vary in relation to age, gender and culture? ii) what images of the future are conveyed by the media, 
computer games, children's comics and books? iii) how do images of the future affect attitudes and behaviour in the present? iv) what determines reactive or proactive stances in relation to the future? v) what changes in attitudes and behaviour arise from extended futuresorientated work in the classroom?

Whatever the debates on the nature of education for sustainability the temporal dimension has to be of paramount concern. Thus the crucial questions 'Where have we come from? Where are we now? Where are we probably heading? Where would we prefer to go?' It is the last two questions that now need to inform all educational work.

\section{References}

ADAMS, B. (2006) In Pursuit of the Future, ESRC Project. Available online at: www.cardiff.ac.uk/socsi/futures/index.html (accessed 29 Sept 06).

BELL, W. (1997) Foundations of Futures Studies, 2 vols. (New Brunswick, NJ, Transaction Publishers).

DATOR (2005) Foreword, in: R. SLAUGHTER, ed. Knowledge Base of Futures Studies, vols. 1-4, Millennium Edition CD Rom (Brisbane, Foresight International).

DATOR, J. (Ed.) (2002) Advancing Futures: futures studies in higher education (Westport CT, Praeger).

DEPARTMENT FOR EDUCATION AND SKILLS (2006) Sustainable Schools (Nottingham, DfES Publications).

DEVINE-WRIGHT, P., DEVINE-WRIGHT, H. \& FLEMING, P. (2004) Situational influences upon children's beliefs about global warming and energy, Environmental Education Research, 10 (4), pp.493-506.

ECKERSLEY, R. (1999) Dreams and expectations: young people's expected and preferred futures and their significance for education, Futures, 31 (1), pp. 73-90.

ELM, A. (2006) Young children's concerns for the future - a challenge for student teachers. Paper presented at conference on 'Children's Identity and Citizenship in Europe' (CiCe), Riga, May 2006.

GIDLEY, J. (1998) Prospective youth visions through imaginative education, Futures, 30 (5), pp.395-408.

GIDLEY, G., BATEMAN, D. \& SMITH, C. (2004) Futures in Education: principles, practice and potential, AFI Monograph 5 (Melbourne, Swinburne University of Technology).

GIDLEY, G. \& INAYATULLAH, S. (Eds.) (2002) Youth Futures: comparative research and transformative visions (Westport CT, Praeger).

HICKS, D. (2006) Lessons for the Future: the missing dimension in education (Victoria BC, Trafford Publishing).

HICKS, D. \& HOLDEN, C. (1995a) Exploring the future: a missing dimension in environmental education, Environmental Education Research, 1 (2), pp. 185-93.

HICKS, D. \& HOLDEN, C. (1995b) Visions of the Future: why we need to teach for tomorrow (Stoke on Trent, Trentham Books).

HICKS, D. \& HOLDEN, C. (Eds.) (2007) Teaching the Global Dimension: key principles and effective practice (London, RoutledgeFalmer).

HOLDEN, C. (2007) Young people's concerns, in: D. HICKS \& C. HOLDEN. (Eds). (2007) Teaching the Global Dimension: key principles and effective practice (London, RoutledgeFalmer).

HUTCHINSON, F. (1996) Educating Beyond Violent Futures (London, Routledge). 
INAYATULLAH, S. (1993) From 'who am I?' to 'when am I?' Framing the shape and time of the future, Futures, 25 (3), pp.235-53.

JUDE, S., BATEMAN, I. \& ANDREWS, J. (2003) Developing techniques to visualise future coastal landscapes, in: E. Buhmann and S.M. Ervin (Eds.) Trends in Landscape Modelling (Heidelberg, Herbert Wichmann Verlag).

LINDSAY, G. (2000) Researching children's perspectives: ethical issues, in A. LEWIS, A \& G. LINDSAY, (eds) Researching Children's Perspectives (Buckingham, Open University Press).

MASINI, B. (1986) Human development and childhood, in: C.A. MALLMAN \& O. NUDLER (Eds.) Human Development in its Social Context: a collective exploration (London, Hodder and Stoughton

MEADOWS, D., RANDERS, J. \& MEADOWS, D. (2005) Limits to Growth: the 30-year update (London, Earthscan).

MORGAN, A. (2006) Teaching geography for a sustainable future, in: D. BALDERSTONE, (Ed.) Secondary Geography Handbook (Sheffield, Geographical Association).

NEWBY, M. (2006) Teaching 2012: the regional seminars (London, Training and Development Agency for Schools).

OSCARSSON, V. (1996) Pupils' views of the future, in: A. OSLER., H-F. RATHENOW \& H. STARKEY, Teaching for Citizenship in Europe (Stoke on Trent, Trentham Books).

PAGE, J. (2000) Reframing the Early Childhood Curriculum: educational imperatives for the future (London, RoutledgeFalmer).

QUALIFICATIONS AND CURRICULUM AUTHORITY. Futures Programme. Available at: www.qca.org.uk/11232.html (accessed 29 Sept 06).

RICKINSON, M. (2001) Learners and learning in environmental education: a critical review of the evidence, Environment Education Research, 7 (3), Special Issue.

ROBERTS, M. (2003) Learning Through Enquiry: making sense of geography in the key stage 3 classroom (Sheffield, Geographical Association).

ROGERS, M. (1996) Facing the future is not for wimps, Futures, 28 (5), pp. 491-6.

RUBIN, A. (2002) Reflections upon the late-modern transition as seen in the images of the future held by young Finns, in: G. GIDLEY, \& S. INAYATULLAH, S. (Eds.) (2002) Youth Futures: comparative research and transformative visions (Westport CT, Praeger).

SARDAR, S. ed. (1999) Rescuing All Our Futures (WestportCT, Greenwood Press)

SLAUGHTER, R. (2004) Futures Beyond Dystopia: creating social foresight (London, Routledge)

SLAUGHTER, R. ed. (2005) Knowledge Base of Futures Studies, vols. 1-4, Millennium Edition CD Rom (Brisbane, Foresight International).

SLAUGHTER, R. with BUSSEY, M. (2006) Futures Thinking for Social Foresight (Brisbane, Foresight International).

TASMANIA DEPARTMENT OF EDUCATION (2002) Essential Learnings. Available online at: www.education.tas.gov.au/school/educators/curriculum/elscurriculum/els1.pdf (accessed 29 Sept 06).

UK CLIMATE IMPACT PROGRAMMES. Available online at: www.ukcip.org.uk/scenarios/ (accessed 29 Sept 06).

WALES, J. \& CLARKE, P. (2005) Learning Citizenship (London, RoutledgeFalmer).

WARREN WAGAR, W. (1992) The Next Three Futures: paradigms of things to come (London, Adamantine Press).

WORLDWATCH INSTITUTE (2005) Vital Signs: the trends that are shaping our future (London, Earthscan). 